\title{
iEREMF
}

\section{Collective Bargaining, Congenial Industrial Relations, and Conflict Resolution in Business Organisations in Nigeria}

\author{
Damilola Esther Olotuah \\ Institute of Graduate Studies and Research, European University of Lefke, North Cyprus
}

\begin{abstract}
:
Industrial peace and harmony is obtained through congenial industrial relations which minimize conflicts in organizations. The objective of the maintenance of industrial peace and harmony is to find out ways and means to resolve conflicts and also to secure the unreserved cooperation of and goodwill among different groups in industry. The objective also aims at the development of a sense of mutual confidence, dependence and respect, and at the same time encouraging the different groups to come closer to one another to remove misunderstanding, redress grievances, and fostering industrial pursuits for mutual benefits and social progress. When two mutually dependent groups seek incompatible goals, conflicts ensue. However conflicts are integral to the process of change and thus some conflict is sometimes needed for innovation and change, and to energize people to activity. Congenial industrial relations are achieved through collective bargaining, which is the process of negotiation between representatives of workers and employers to establish conditions of employment, and for winning improvements in the working conditions of workers. This paper examines collective bargaining as a means of achieving congenial industrial relations in business organizations in Nigeria for the purpose of conflict resolution. It examines conflict management styles and negotiation strategies, and the role of the Nigeria Labour Congress (NLC) in collective bargaining. The paper asserts that negotiation is a very effective conflict-resolution strategy, and collective bargaining is important in achieving social, political, and economic transformation through increased productivity, job security, motivation, and involvement of all workers.
\end{abstract}

Keywords: bargaining; conflict; industrial relations; negotiation; Nigeria. 